\title{
Physical Properties of the Probiotic Effervescent Tablet from Tapioca and Maltodextrin Coatings
}

\author{
Devi Ambarwaty Oktavia ${ }^{1 *}$, Diah Lestari Ayudiarti ${ }^{1}$ and Dita Febrianti $^{2}$ \\ ${ }^{1}$ Research and Development Center for Marine and Fisheries Product Processing and Biotechnology, \\ Jakarta \\ ${ }^{2}$ Directorate of Fishing Port, Directorate General of Capture Fishing Port, Jakarta
}

\begin{abstract}
The purpose of this study was to determine the physical properties of probiotic effervescent tablets with two different coatings that are tapioca and maltodextrin to improve water quality in shrimp farming ponds. This study used probiotics to improve the environmental quality of shrimp pond waters. Liquid probiotics from Research Institute for Coastal Aquaculture in Maros, South Sulawesi that contain Brevibacillus laterosporus. Probiotics that have been used are liquid and difficult to transport, therefore microencapsulation is carried out on liquid probiotics aimed at facilitating their distribution. The use of microencapsulating materials is to entrap or immobilize probiotic bacteria within microcapsule and to protect the bacteria during the drying process. Effervescent tablets were prepared in a dosage of $800 \mathrm{mg}$ by wet granulation methods. This experiment was replicated 3 times. Tablets were evaluated for their physical properties there are mean weight, friability, hardness, disintegration time and $\mathrm{pH}$. The results showed that mean weight for effervescent tablets with maltodextrin coatings was $796 \mathrm{mg}$, had a friability value $0.09 \%$, a hardness value of $13.7 \mathrm{~N}$ and disintegration time of 10.68 minutes. Both probiotic effervescent tablets meet the standards $\mathrm{pH}$ of 7.07 and 6.67. The maltodextrin coatings was the best treatment of this study.
\end{abstract}

\section{Introduction}

Alternative efforts to overcome disease in fishery commodities are the use of probiotic bacteria that are non-pathogenic, have the ability to inhibit and kill pathogenic bacteria, inhibit communication between pathogenic bacterial cells so that quorum sensing can be prevented, and can function as decomposing bacteria and neutralizing water quality as well as food in the water [1]. The bacteria commonly used for probiotics in shrimp include Bacillus sp., Bacillus subtilis, Lactobacillus spp., Brevibacillus sp., Pseudomonas sp., Pseudoalteromonas sp., Vibrio alginolyticus and Vibrio carcarie [2].

Probiotics can improve water quality, regulate the condition of microorganisms, increase the diversity of microorganisms, and minimize the effects of pathogenic bacteria [3]. The encapsulation efficiency and the microsphere stability are greatly dependent on the encapsulating material known as wall material. The wall material should be water soluble

\footnotetext{
*Corresponding author: devi_oktav@yahoo.co.uk
} 
since most spray drying suspensions are water based and have good mechanical strength, compatibility with the core materials, emulsification properties and film forming and low viscous properties [4]. The effective wall materials for spray drying should have functional properties, including good emulsification, film forming, high solubility, low viscosity at high concentrations and low cost properties. Native tapioca starch had more rigid or tight crystalline structure and high viscosity as compared to modified tapioca starch and these could influence rate of drying [22]. Starch is a wall material that is widely used for microencapsulation purpose. Unmodified and modified starches are increasingly considered for microencapsulation of vitamins, essential oils, flavors, drugs, and microorganism [23]. Starches are abundant and cheap encapsulating agents that protect encapsulated ingredients from oxidation. Native starches present several limitations, which restrict their use as encapsulating agents [24]. Maltodextrin offered good adherence to the probiotics during drying and storage [4]. Microcapsules prepared with native starch showed the lowest stability during storage [25].

The use of probiotics can reduce the use of disinfectants, antiseptics and antibiotics so that shrimp are safe for consumption. Disease attacks do not only occur at the cultivation level but at the hatchery level [5]. The attack was caused by fluorescent bacteria, Vibrio harveyi. Prevention of disease in tiger shrimp cultivation is to stimulate non-specific immunity through the use of vaccines and immunostimulants and use of probiotics [5,6]. The advantage of using probiotic bacteria is to prevent shrimp disease because it is safer than various chemicals; not accumulating in the food chain; the reproductive process that can reduce repeated use; rare target organisms that become resistant to probiotic agents compared to their resistance to chemicals or antibiotics; can be used together by means of existing protection [7].

Maltodextrin is basically a result of imperfect hydrolysis of starch or partial hydrolysis, which consists of a mixture of sugars in a simple form (mono- and disaccharide) in small quantities. The function of adding Maltodextrin is used in liquid probiotics to give mouthfeel, filler during drying and as thickener [8].

Effervescent tablets are one of the tablet dosage forms made by compressing active ingredients with a mixture of organic acids, such as citric acid or tartrate acid and sodium bicarbonate [9]. Effervescent tablets are practical products because they are easy to consume, quickly dissolve in water without having to stir, give sparkle effects like in soda drinks and have a longer shelf life. Effervescent tablet formulas contain basic ingredients and some additional ingredients [10,11]. Additional materials function as fillers, adhesives, crushers and lubricating materials. Additional ingredients used in the manufacture of effervescent tablets must be soluble so they do not produce residues when dissolved.

This study aims to determine the physical properties of probiotic effervescent tablets that use different coatings, namely maltodextrin and tapioca. The results of testing the physical properties will determine the best probiotic effervescent tablet formulations to be used in shrimp ponds.

\section{Materials and methods}

\subsection{Preparation probiotic powder}

Liquid probiotics RICA Super (RICA 1) (Research Institute for Coastal Aquaculture) used in this experiment contains Brevibacillus laterosporus which isolated from ponds. The bacteria was cultured on Nutrient Broth supplemented with fish meal, rice bran, yeast, molasses or sugar cane or sugar and incubated at $40^{\circ} \mathrm{C}$ as the optimum growth temperature. Liquid probiotic was then suspended into $20 \%$ maltodextrin or $20 \%$ tapioca in $50 \mathrm{~mL}$ of 
water as treatments. This suspension was incubated at $37^{\circ} \mathrm{C}$ for 30 minutes with a constant rotation to adapt the mixture, before drying with a spray dryer. Probiotic powder is ready to be used after coming out of the dryer (spray dryer). The temperature of the spray dryer inlet is $160^{\circ} \mathrm{C}$ and the outlet is $40^{\circ} \mathrm{C}[6,12]$.

\subsection{Preparation of effervescent tablets}

To improve flow ability, granules are first made and then added to the effervescent mixture. Granules are made with the aim of protecting the bacteria in addition to protect materials also intended to prepare bacteria with temporary media containing carbon sources and nitrogen sources. Modified effervescent tablet formula are shown in Table 1 [13, 14].

Table 1. Modified effervescent tablet formula

\begin{tabular}{|l|c|}
\hline \multicolumn{1}{|c|}{ Ingredients } & Quantity (mg) \\
\hline Probiotics powder & 300 \\
\hline Citric acids & 80 \\
\hline Sodium bicarbonate & 320 \\
\hline Magnesium stearate & 10 \\
\hline Lactose & 90 \\
\hline Amount & 800 \\
\hline
\end{tabular}

The modification made is the ratio of citric acid with sodium bicarbonate is $1: 1,1: 2,1: 3$ and 1:4. Based on the results obtained in the tests assessing the influence of the excipients, the best formulation to manufacture the tablets was achieved. Effervescent tablets contain acids and carbonates or bicarbonates which react quickly to the addition of water by releasing carbon dioxide gas [30]. The ratio of acids and bases in effervescent tablets that affect the effects of carbonation will also affect the physical properties of hardness, friability and disintegration time of tablets.

Effervescent tablets that have physical properties meet the standards to be selected. Acid is present in the composition in an amount $10 \%$ by weight to about $60 \%$, more preferably from about $25-40 \%$ by weight using stevia. The base is present in the composition in an amount of from $10 \%$ by weight to about $60 \%$ by weight, more preferably from about $15 \%$ by weight to about $50 \%$ by weight [26]. The acid composition that used in this research are $10 \%$ and base composition $40 \%$ by weight.

\subsubsection{Mixing ingredients}

Before tableting, the ingredients used are first mixed evenly at room RH 40\%, prevent the occurrence of hygroscopic of acidic material. The mixing process uses wet granulation which is separating between acidic ingredients, namely citric acid and alkaline namely bicarbonate sodium. 


\subsubsection{Tablet forming}

Tablet forming can be done by compression method [11]. Material that has been mixed with the specified formula is put into the mold, then compressed with a pressing force. Tablet printing uses a mini tablet press machine.

\subsection{Physical properties of tablets [15]}

\subsubsection{Mean weight}

A total of 10 tablets were weighed randomly using analytical scales (brand MettlerTOLEDO) to determine their mean weight; a 5\% deviation was considered acceptable.

\subsubsection{Hardness}

Hardness was measured using a hardness tester (brand Erweka, model TBH-30). The results obtained were averages of 10 tablets and expressed in Newton $(\mathrm{N})$. The recommended minimum value for hardness is $30 \mathrm{~N}$.

\subsubsection{Friability}

The parameter is determined using a friabilometer (brand Erweka, model TAR). A total of 10 tablets were submitted to a $25 \mathrm{rpm}$ for 4 minutes, a weight loss maximum value of $1 \%$ was considered acceptable.

\subsubsection{Disintegration}

The disintegration time of the six tablets was determined using a disintegration apparatus (brand Erweka, model ZT3) and distilled water at $37 \pm 2^{\circ} \mathrm{C}$ as a disintegration media. Disintegration time limit for the effervescent tablet for 5 minutes is considered acceptable.

\subsubsection{Data Analysis}

Data and statistics analysis were made by using analysis of variant (one way ANOVA). A value of $\mathrm{p}<0.05$ was considered significant statistically.

\section{Results and discussion}

It can be seen in Figure 1 that the uniformity of the weight of the effervescent tablets produced by probiotics fulfills the requirements, namely the standard deviation should not exceed $10 \%$ for tablets weighing above $300 \mathrm{mg}$ [16]. It can be concluded that all of the probiotic effervescent tablets produced have uniformity of weight that meets the requirements in the Indonesian Pharmacopoeia. In accordance with the results of the study, that if the granules with good flow properties will be easy to flow and easy to press when tableting, resulting in tablets with smaller weight variations [14]. The result of statistical analysis using one way ANOVA showed that mean weight of tablet from different coatings were significantly different $(\mathrm{p}<0.05)$. 


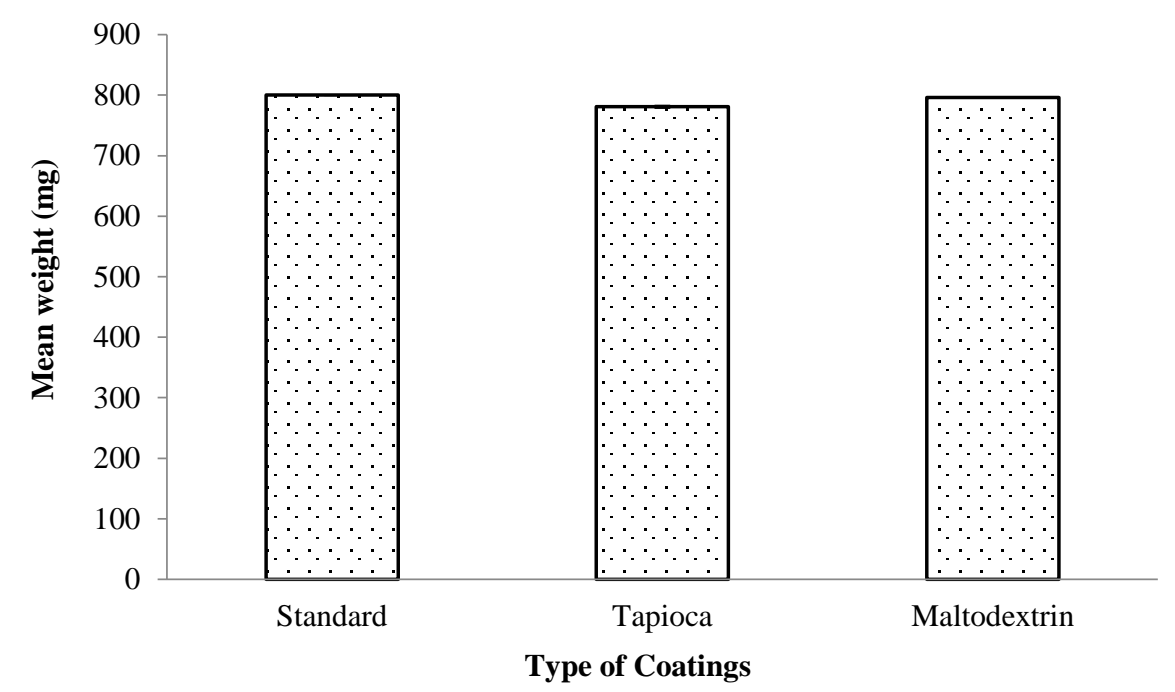

Fig. 1. Mean weight of probiotic effervescent tablet from different coatings

Testing for friability (fragility) needs to be done because tablet hardness is not an absolute parameter of tablet strength. Fragility of tablets illustrates the physical strength of the outside of the tablet which has a role in fighting mechanical shocks. Good tablets have a value of clarity (fragility) of no more than 1\% [14]. Effervescent probiotic tablets with maltodextrin coating have a value of 0 which means that they meet the required effervescent tablet clarity requirements. Seen from Figure 2, effervescent tablets of probiotics with tapioca coating have a value of $54.43 \%$, consequently these tablets break easily and quickly dissolve while touching the surface of the water. Fragile tablets will dissolve immediately and break on the surface of the water, so the solubility is relatively faster. In accordance with the results of research, that fragile tablets usually have a faster solubility [13]. The high compressive force during pressing causes the tablet density to be small, so that fluid penetration into the tablet structure becomes difficult. This affects the dissolution time of the tablet. When probiotic effervescent tablets from tapioca coatings get heat from pressure during the tablet printing process, then the strength will break so that the water will migration to the granules and the addition of water-soluble components will occur [22]. The disadvantage of the wet granulation method is that when it is moistened with excessive ethanol it usually produces granules that are too hard to make a good tablet, conversely if wetting is lacking it will produce tablets that are too soft and tend to break easily [27]. 


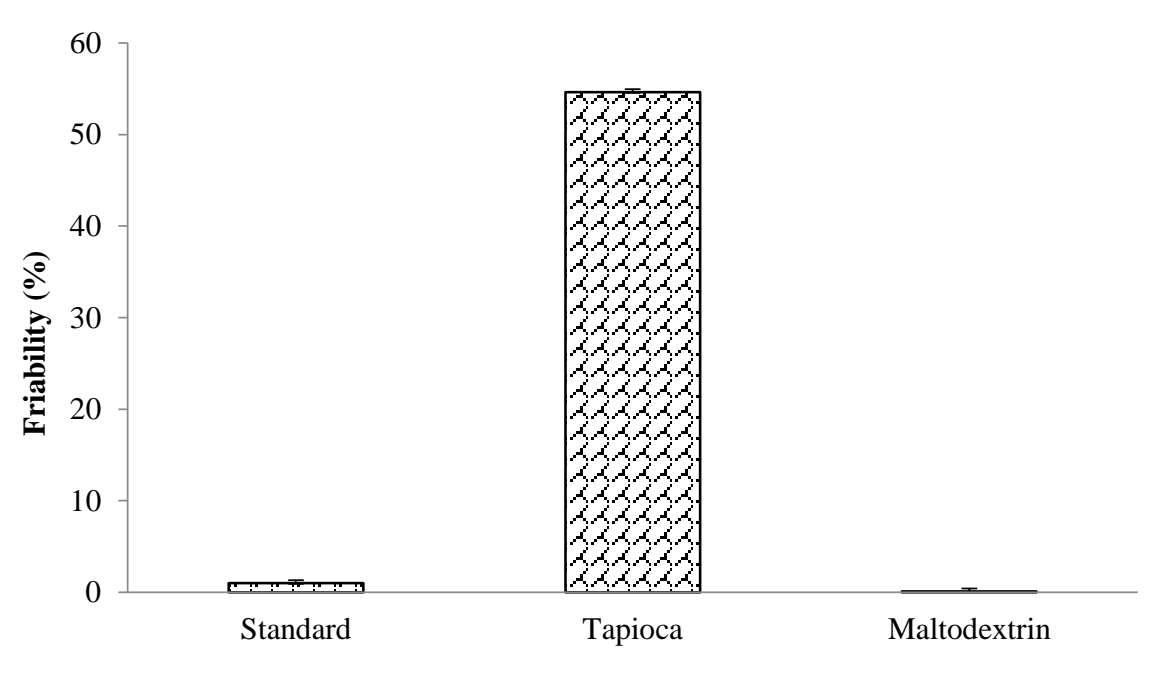

Type of Coatings

Fig. 2. Friability of probiotic effervescent tablet from different coatings

The resulting effervescent tablets of probiotics did not meet the tablet hardness requirements of 6-12 kg [17], which is seen in Figure 3, but fulfilled the requirements for tablet effervescent hardness required which is a maximum of $30 \mathrm{~kg}$ [15]. This hardness test aims to determine the ability of the tablet in packaging against mechanical pressure and impact. Hardness is influenced by pressure during tableting, the nature of the binding material and the right filler and lubricant [14]. Hardness of a tablet is directly proportional to the logarithm of the compression force and inversely proportional to porosity (i.e., the higher the compression force, the lower the porosity and the higher the resistance, hardness, and disintegration time) [15]. Probiotic effervescent tablet from tapioca coatings had a higher friability and lower hardness than maltodextrin coating. This is due to the core material released from the encapsulation material is driven by changes in $\mathrm{pH}$, temperature, diffusion by the action of external fluids, chemical reactions, enzymatic or mechanical hydrolysis broken [23]. The result of statistical analysis using one way ANOVA showed that friability of tablet from different coatings were significantly different $(p<0.05)$. 


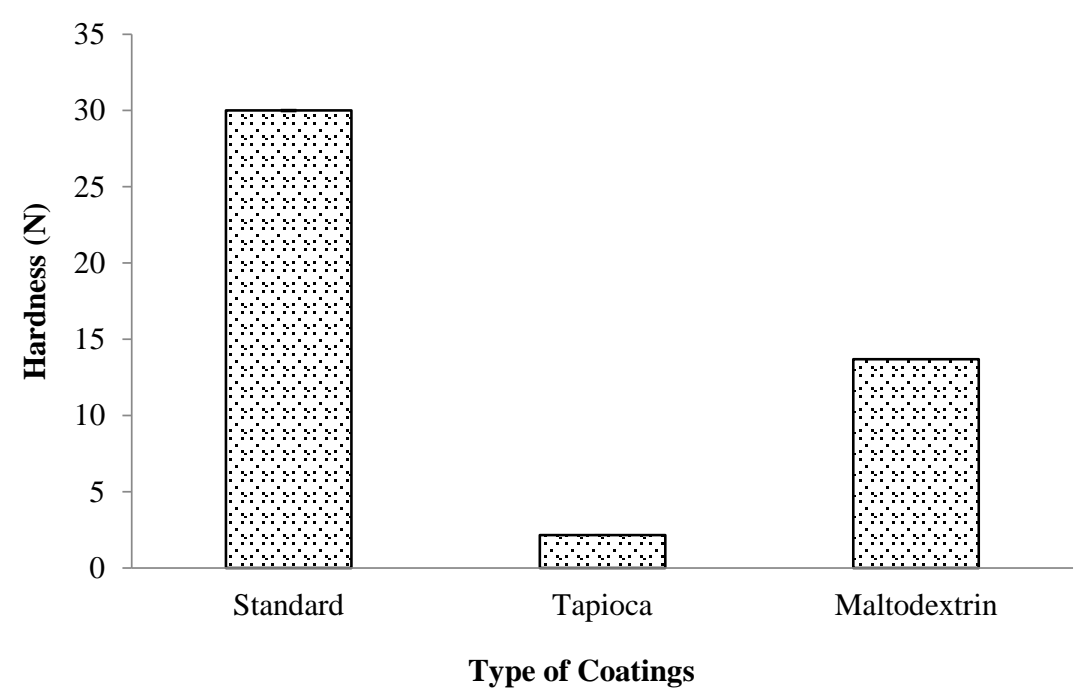

Fig. 3. Hardness of probiotic effervescent tablet from different coatings

It can be seen from Figure 4 that the soluble time of the effervescent tablets produced did not meet the standard physical properties applied namely for 5 minutes [16], while applied effervescent physical properties have 1-2.5 minutes of dissolution time [18]. The soluble time of the effervescent tablets produced is not used for human consumption, so it does not affect if applied to the aquaculture environment. Tartrate acid provides a longer disintegration time than citric acid even though it forms more $\mathrm{CO}_{2}$ [14]. Comparison of sodium bicarbonate with citric acid greatly affects the solubility of the tablet, the high fraction of sodium bicarbonate will cause faster solubility [13]. The result of statistical analysis using one way ANOVA showed that hardness of tablet from different coatings were significantly different $(\mathrm{p}<0.05)$.

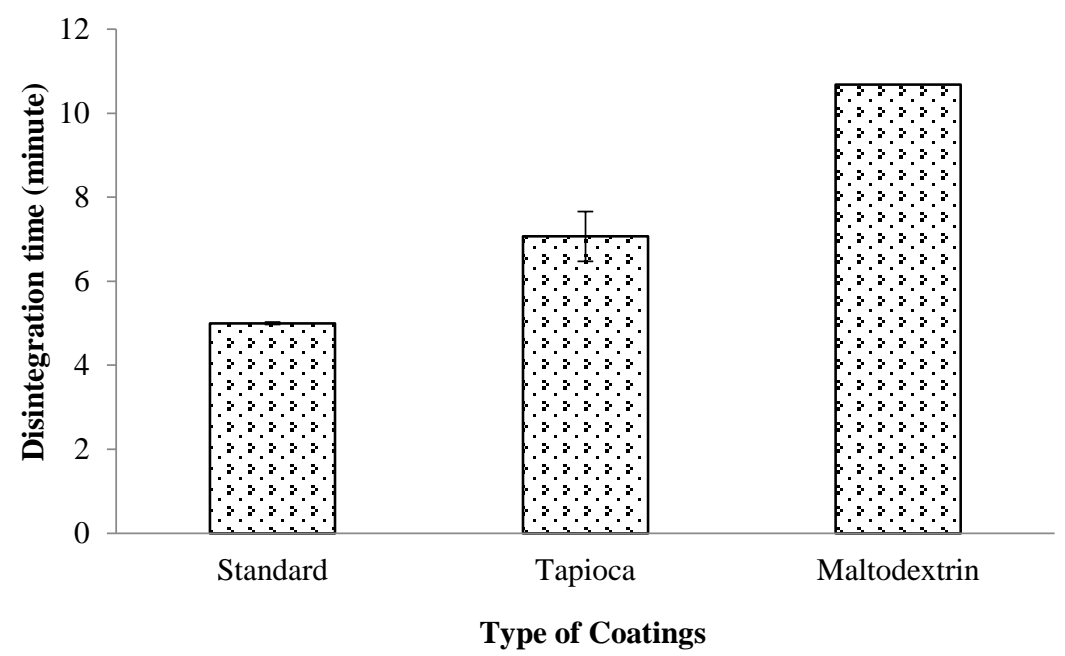

Fig. 4. Disintegration time of probiotic effervescent tablet from different coatings

The $\mathrm{pH}$ produced in the effervescent tablet dissolution has a neutral $\mathrm{pH}$ which is 7 seen in Figure 5. This meets the $\mathrm{pH}$ requirements in the aquatic environment is around 7.5-8.7 [19, 20]. This condition is a characteristic of sodium bicarbonate which can increase the $\mathrm{pH}$ of 
water. These results indicate that the $\mathrm{pH}$ range produced is neutral and can be accepted by pond shrimp that live in the range 6.5-8.5 [21].The $\mathrm{pH}$ in the effervescent solution will affect its solubility and stability [29]. The result of statistical analysis using one way ANOVA showed that disintegration time tablet from different coatings were significantly different $(\mathrm{p}<0.05)$.

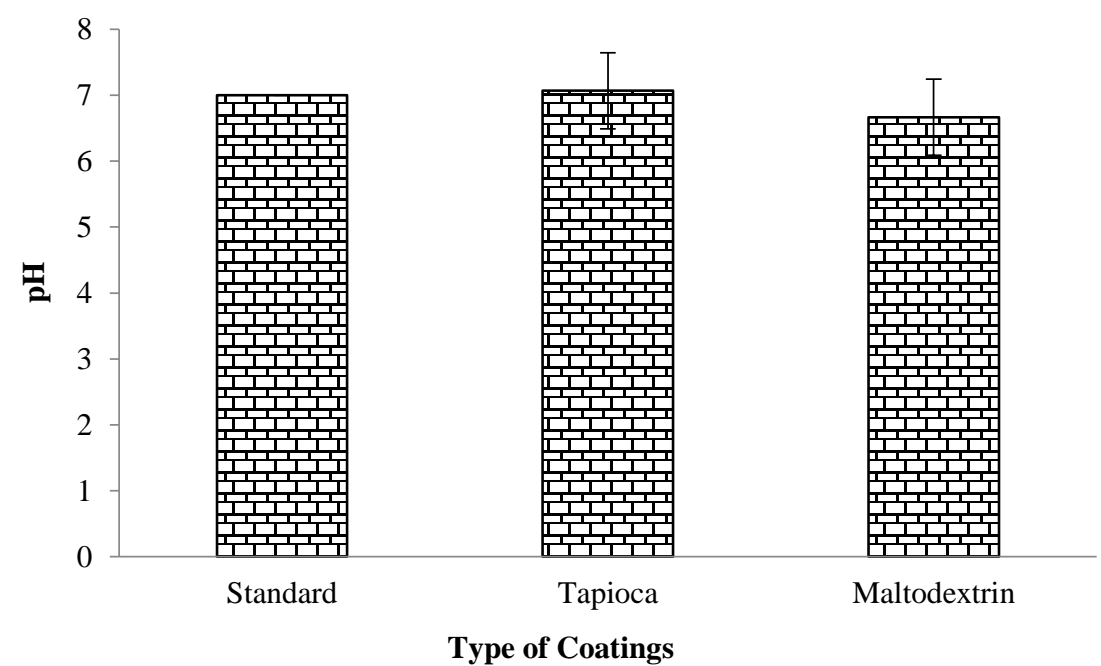

Fig. 5. $\mathrm{pH}$ of probiotic effervescent tablet from different coatings

From the results, the product that can be developed is effervescent probiotics with maltodextrin coatings, because it has physical characteristics that are close to the standard, the materials used are relatively inexpensive.

The industrial scale production of the effervescent probiotic tablet was performed using talcum in the formulation, which is an anti-aggregating binder, diluent and lubricant agent of capsules and tablets and magnesium stearate, which is also a lubricant and an anti-binder excipient. In order to be available on the market, tablets must undergo numerous studies and tests. Pharmacopoeia determines the acceptable limits for the many quality criteria that the tablet formulations must possess to be approved. By meeting the established quality criteria, the maximum safety of the product is guaranteed and assurance that it can be safely consumed by people is provided. Formulation of powder effervescent probiotics is more promising from an industrial point of view because of the better viability of the product during storage, in addition to the fact that the production of the powder compared with the production of tablets requires the use of fewer ingredients and fewer pieces of equipment (compressor, durometer, disintegrator and friabilometer), which means smaller investment [15].

\section{Conclusion}

The weight uniformity and $\mathrm{pH}$ of the resulted effervescent tablets of probiotics met the requirements of a maximum standard deviation of $10 \%$ and $\mathrm{pH}$ 7. The firmness analysis showed that only effervescent tablets of probiotics with maltodextrin treatment met the requirements. Solubility of the two tablets has not met the requirements, namely 5 minutes, but can be ignored because it is used in the aquaculture environment. Both effervescent tablets of probiotics do not meet tablet hardness standards of at least $30 \mathrm{~kg}$. 


\section{References}

1. Suwanto A, Yogiara, Suryanto D., Tan I. and Puspitasari, E. Selected Protocols. Training Course on Advances in Molecular Biology Techniques to Assess Microbial Diversity (Bogor, 28 pp., 2000).

2. Muliani, Nurbaya and Atmomarsono, M. Prosiding Forum Inovasi Teknologi Akuakultur, 249-259. (2010).

3. Pribadi. Probiotik Dalam Budidaya. Kumpulan Majalah Mitra Bahari Edisi 1996-2002. hal 5. (2002).

4. Anekella, K. (Thesis, McGill University. 128 p., 2011).

5. Muliani, Nurbaya dan Madeali MI. J. Riset Akuakultur 6(1), 81-92 (2011).

6. Oktavia, DA and Martosuyono, P. Prosiding Seminar Nasional Hasil Litbang Pengolahan Produk dan Bioteknologi Kelautan dan Perikanan, 195-200 (2016).

7. Atmomarsono M, Muliani dan Tampangallo BR. Prosiding Forum Inovasi Teknologi Akuakultur, 269-278 (2010).

8. Fardinatri. I.D. Pengembangan dan Evaluasi Tepung Tablet Isap Kaya Antioksidan Berbahan Dasar Tomat, Fakultas Pertanian, Institut Pertanian Bogor, Bogor (2007).

9. Pribadi, YS, Sukatiningsih and Sari, P. Berkala Ilmiah Pertanian 1(4), 86-89 (2014).

10. Ansel, H.C., Robinson JR, and Ericsson T. Journal Pharmaceutical Science 77(4), 214217 (1989).

11. Mohrle, R., Attwood D., and Banker CS. Tropical Journal of Pharmaceutical Research 2(1), 285-286 (1989).

12. Teixeira, P., Castro, H., and Kirby, R. Spray drying as a method for preparing concentrated cultures of Lactobacillus bulgaricus. Pp. 7. www.repositorio.ucp.pt (1995).

13. Ansar, Rahardjo B, Noor Z and Rochmadi. J. Teknol. dan Industri Pangan XX (1), 2531 (2009).

14. Anwar, K. Sains dan Terapan Kimia 4 (2), 168-178 (2010).

15. Nagashima, AI, Pansiera, PE, Baracat, MM and Gomez, RJHC. Food Sci. and Technol. 33(4), 605-611 (2013).

16. Directorate General of Drug and Food Control. Farmakope Indonesia. Edisi III (Departemen Kesehatan Republik Indonesia, Jakarta, 1979).

17. Parrot, E.L. Pharmaceutical Technology Fundamental Pharmaceutics. edisi 3 (Burgess Publishing Company. Minnepolis, 64-66, 73-83, 1971).

18. Wehling and Fred. Effervescent Composition Including Stevia. (2004).

19. Kailaku, S.I., Sumangat J., and Hernani. J. Pascapanen 9(1), 27 - 34 (2012).

20. BPPT. P3TL-BPPT 4(2), 62-67 (2003).

21. Purwanta W., and Firdayati M. Jurnal Teknik Lingkungan 3(1), 61-65 (2002).

22. Loksuwan, J. Food Hydrocolloid 21, 928-935 (2007).

23. Hoyos-Levya, JD, Bello-Perez, LA, Alvarez-Ramirez, J. and Garcia, HS. Food Review Int., 1-31 pp. (2016).

24. Spada, JC, Norena, CPZ, Marczak, LDF. and Tessaro, IC. Carbohydrate Plymers 89, 1166-1173 (2012).

25. Ozkan, G. and Bilek, SE. Int. J. of Nutrition and Food Sciences 3(3), 145-156 (2014)

26. Wehling, F. Effervescent Composition Including Stevia. US Patent No. 6,811,793 B2 (2004).

27. Hartono, HP. (Skripsi Institut Pertanian Bogor, 2008).

28. KPRI MINA LESTARI dan Balai Riset Perikanan Budidaya Air Payau dan Penyuluhan Perikanan. RICA Packaging (2019).

29. Lestari, ABS dan Trisusilawati, MY. Majalah Farmasi Indonesia 21(4), 231-237 (2010). 
30. Lindberg, N., Engfors, H. and Ericsson, T. Effervescent Pharmaceutical in Swarbrick, J., Boylan, J.C., (Eds.), Encyclopedia of Pharmaceutical Technology, vol. 5 (Mercel Dekker inc., New York, 45-71, 1992). 